\title{
Long Noncoding RNA RGMB-ASI Acts as a microRNA-574 Sponge Thereby Enhancing the Aggressiveness of Gastric Cancer via HDAC4 Upregulation [Retraction]
}

\author{
Wang X, Chen X, Tian Y, Jiang D, Song Y. Onco Targets \\ Ther. 2020;13:1691-1704.
}

The Editor-in-chief and Publisher of OncoTargets and Therapy wish to retract the published article. Concerns were raised of alleged image duplication occurring in flow cytometry images found within the article and across other publications for unrelated studies. Specifically:

- Figure 2C panel AGS si-RGMB-AS1, Figure 4C panel MGC-803 agomir-574 and Figure 6B panel MGC-803 si-RGMB-AS1+antagomir-NC all share an acceptable level of similarity to each other and images found in:

o Figure 4B panel Eca109 miR-411 mimics and Figure 6C panel TE-1 miR-411 mimics + pcDNA3.1 published in Song et al, 2019 (https://doi.org/10.2147/OTT.S214881).
- Figure 2C panel MCF-7 si-LINC02163 published in Qin et al, 2020 (https://doi.org/10.3727/ 096504020X15928179818438).

The authors responded to our queries but were unable to provide a satisfactory explanation for the alleged duplication or provide raw data for the flow cytometry experiments. It was determined the findings of the study could not be supported and the decision was made to retract the article. The authors agree with this decision.

Our decision-making was informed by our policy on publishing ethics and integrity and the COPE guidelines on retraction.

The retracted article will remain online to maintain the scholarly record, but it will be digitally watermarked on each page as "Retracted".

\section{Publish your work in this journal}

OncoTargets and Therapy is an international, peer-reviewed, open access journal focusing on the pathological basis of all cancers, potential targets for therapy and treatment protocols employed to improve the management of cancer patients. The journal also focuses on the impact of management programs and new therapeutic agents and protocols on patient perspectives such as quality of life, adherence and satisfaction. The manuscript management system is completely online and includes a very quick and fair peer-review system, which is all easy to use. Visit http://www.dovepress.com/ testimonials.php to read real quotes from published authors. 